\title{
OCCURRENCE OF ANTI-NEOSPORA CANINUM ANTIBODIES IN BEEF CATTLE OF MICRORREGION OF GUARAPUAVA, PARANÁ STATE, BRAZIL
}

\author{
A.B. de Moura ${ }^{1}$, S.C. Osaki ${ }^{2}$, D.L. Zulpo ${ }^{3}$, J.L. Garcia ${ }^{3}$, E.B. Teixeira ${ }^{1}$ \\ ${ }^{1}$ Universidade do Estado de Santa Catarina, Centro de Ciências Agroveterinárias, Departamento de Medicina \\ Veterinária, Av. Luís de Camões, 2090, CEP 88520-000, Lages, SC, Brasil. -E-mail: a2abm@cav.udesc.br
}

\begin{abstract}
Occurrence of anti-Neospora caninum antibodies in blood samples of 250 bovine beef cattle of the microrregion of Guarapuava, Paraná State was verified by Indirect Fluorescent Antibody Test (IFAT) ( $\geq 1: 200)$ and correlated to age, sex and breed of animals. The statistical analysis was carried out through Fisher's Exact and qui-square tests $(p \leq 0.05)$ to associate the results of the serology with the analyzed variables. From 250 evaluated samples, 33 (13.2 \%) were positive for $N$. caninum. The titles obtained for $N$. caninum were 1:200 (8), 1:400 (14) and 1:800 (11). Seropositives animals were present in $40 \%(10 / 25)$ of the evaluated properties. These results demonstrate wide distribution of the protozoa among the beef cattle in the region of Guarapuava, PR. Animals without defined breed showed higher rates of seropositives for $N$. caninum $(P=0.002)$. The age had positive association with the incidence of antibodies against $N$. caninum $(P=0.02)$, indicating that horizontal transmission plays an important role in the epidemiology of this coccidia.
\end{abstract}

KEY WORDS: Serology, IFAT, epidemiology.

\section{RESUMO}

OCORRÊNCIA DE ANTICORPOS CONTRA NEOSPORA CANINUM EM BOVINOS DE CORTE DA MICRORREGIÃO DE GUARAPUAVA, PR, BRASIL. Com os objetivos de verificar a ocorrência de anticorpos contra Neospora caninum em bovinos de corte da microrregião de Guarapuava, Paraná, e de correlacioná-la com a idade, o sexo e a raça dos animais, amostras de sangue de 250 bovinos foram analisadas por meio da Reação de Imunofluorescência Indireta ( $\geq 1: 200)$. A análise estatística foi realizada por meio dos testes exato de Fisher e de qui-quadrado $(p \leq 0,05)$ para correlacionar os resultados da sorologia com as variáveis analisadas. Das 250 amostras avaliadas, $33(13,2 \%)$ foram positivas para N. caninum. Os títulos obtidos para N. caninum foram 1:200 (8), 1:400 (14) e 1:800 (11). Animais soropositivos estavam presentes em 40\% (10/25) das propriedades avaliadas. Os resultados demonstram ampla distribuição do protozoário entre os rebanhos bovinos de corte na região de Guarapuava, PR. Animais sem raça definida apresentaram maiores índices de soropositivos para $N$. caninum $(\mathrm{P}=0,002)$. A idade apresentou associação positiva com a ocorrência de anticorpos contra $N$. caninum $(\mathrm{P}=0,02)$, indicando que a transmissão horizontal tem importante papel na epidemiologia do coccídio.

PALAVRAS-CHAVE: Sorologia, RIFI, epidemiologia.

Neosporosis was initially described in dogs with neuromuscular disorders in Norway (BJERKÅs et al., 1984). Though similar to the Toxoplasma gondii, it differs by its ultra-structure and antigenic properties (BARR et al., 1991).

The bovine infection occurs after ingestion of sporulated oocysts or by the transplacental route (DuBEY; LinDSAY, 1996). Lactogenic/colostral transmission can also occur. Approximately 80\% of the bovine infections originate from the vertical transmission, considered the major form of transmission of N. caninum in cattle (DAvISON et al., 1999).

The main clinical sign of bovine neosporosis is the abortion and stillborn calves or infected born alive have been reported (WALDNER, 2005). Reduction in

${ }^{2}$ Universidade Federal do Paraná, Palotina, PR, Brasil.

${ }^{3}$ Universidade Estadual de Londrina, Centro de Ciências Agrárias, Departamento de Medicina Veterinária Preventiva, Londrina, PR, Brasil. 
weight gain, carcass yield and income (BARLING et al., 2000), along with reduction in milk production, increase of embryonic mortality and culling rate, ill birth calves or with deficit of development also are consequences of $N$. caninum infection.

The occurrence of cattle showing antibodies against $N$. caninum varies in the many different regions of Brazil, with values ranged from zero up to $72.73 \%$ (Melo et al., 2001), from $6.8 \%$ to $67.8 \%$ (GENNARI, 2004) and 19\% (MinERVINO et al., 2008).

Due to the importance of $N$. caninum in bovine herds' health status in the whole world, this work aimed to describe the occurrence of antibodies against $N$. caninum in bovines slaughtered in Guarapuava, $\mathrm{PR}$, as well as to establish association between the occurrence of this infection with the age, sex and breed of beef cattle.

From January to July 2005, 250 blood samples were taken from beef cattle, from 25 farms from eight municipalities (Candói, Guarapuava, Inácio Martins, Laranjeiras do Sul, Nova Laranjeiras, Pinhão, Reserva do Iguaçu and Turvo) of the microrregion of Guarapuava, middle west of Paraná State, at the moment of bleeding in a slaughtering house(equivalentto $10 \%$ of thetotalofanimals slaughtered in the period). The center-south mesoregion of the State of Paraná concentrated 1,239,436 cattle and $55.5 \%(688,450)$ of these are in the microregion of Guarapuava (IBGE, 2010). The slaughtering of cattle occurred on specific days of the week, according to the place of origin, and the collections they ran daily, than all the properties have been covered. The samples, properly identified and conditioned, were sent to the Laboratório de Zoonoses e Saúde Pública, Departamento de Medicina Veterinária Preventiva (DMV), Universidade Estadual de Londrina (UEL). Serum samples were stored at $-20^{\circ}$ $\mathrm{C}$, until the lab assays. Information about breed, sex and age of the slaughtered animals were also obtained (Table 1).

The detection of IgG antibodies anti-N. caninum was carried out through Indirect Immunofluorescence Antibody Test (IFAT) according to CONRAD et al. (1993), using tachyzoites of the NC1 strain of N. caninum as antigen and rabbit-anti-bovine IgG (whole molecule) FITC as the conjugate (Sigma-Aldrich). The dilution 1:200 was used as cut-point (DUBEY ; LINDSAY, 1996). Bovine positive and negative serums were used as control. The negative control is serum of fetus, is being tested by IFAT. The positive control is serum of aborted cow, with positive immunohistochemical analysis of fetus, positive in IFAT. Slides were observed under 40x magnification using epifluorescence microscopy (Leica ${ }^{\circledR}$-DMLB-30S). Positive sera in the dilution 1:200 were diluted two-fold until the end point. Data were tabulated and analyzed statistically by Fisher's exact (R DevelopmEnT CORE
TEAM, 2008) and qui-square tests ( $\mathrm{p} \leq 0.05)$ in order to associate the results of serology and variables.

From 250 serum samples evaluated, 33 (13.2\%) were positive for N. caninum antibodies. Theobserved titles were 1:200 (8), 1:400 (14) and 1:800 (11).

Seropositives animals were present in 10 of 25 farms $(40 \%)$. Results demonstrate distribution of the protozoa among the beef cattle herds in the region of Guarapuava, PR. High values as 95\% (STOESSEL et al., 2003) in Australia, 69.2\% (BANALEs et al., 2006) in Uruguay, $81.25 \%$ (MinERvino et al., 2008) in the state of Pará, Brazil and 70.9\% (GARCIA-VAZQuez et al., 2009) in Mexico, of farms with positive animals were found by other authors, who used different techniques and/or cut off from the present work.

In South America, seroprevalence to neosporosis bovine has already been described in Paraguay (29.8\%) and Uruguay (13.9\%) (OsawA et al., 2002; BANALES et al., 2006).

In Brazil, similar results (11.4\%) to those found in this study were described by VoGel et al. (2006) and higher values $(20 \%, 23.6 \%, 30.4 \%)$ were described by SARTor et al. (2005), RAgOzo et al. (2003) and Melo et al. (2006).

In Goiás State, MeLo et al. (2006) observed a predominance (IFAT, cut off $\geq 1: 250$ ) of $30.4 \%$ for $N$. caninum in bovine, with no statistical difference between beef and dairy cattle herds. MinERVINO et al. (2008) also did not observe differences between beef and dairy cattle. RAGOZO et al. (2003) and SARTOR et al. (2005) reported higher occurrence of seropositive animals in dairy than in beef cattle. PRANDO MOORE et al. (2002), in Argentina, identified high association between neosporosis and dairy cattle, although they have shown that $N$. caninum is also an important risk factor for reproductive loss in beef cattle.

It was observed significant association (Table 1) between the occurrence of antibodies against $N$. caninum in cattle and the variables age $(\mathrm{P}=0.02)$ and breed $(\mathrm{P}=0.002)$.

The age of analyzed animals varied from six to 48 months. Among the seropositive bovines, $63.6 \%$ were older than 24 months, indicating that the horizontal transmission occur with higher frequency in the evaluated herds. The same finding was reported by RAGOZO et al. (2003), GUIMARÃes Junior et al. (2004) and ARMENGol et al. (2007).

Of the positive animals, $69.7 \%$ were crossbred. Differences in the seroprevalence of $N$. caninum in bovine in function of the breed were observed by BARTELs et al. (2006) and ARMENGol et al. (2007). However, in the works of those authors the interference of the breed seemed to be more connected to the type of handling, mainly the pasture capacity, than to the genetics of the animals. Sex did not show association $(\mathrm{P}=0.13)$ with the soropositivity of the bovine to N. caninum. 
Table 1 - Occurrence of Neospora caninum IgG antibodies (IFAT, 21:200) from beef cattle of Guarapuava City, Paraná State, Brazil, for each analyzed variable and total.

\begin{tabular}{|c|c|c|c|c|c|c|c|}
\hline \multirow{2}{*}{ Variable } & \multirow{2}{*}{ Category } & \multicolumn{2}{|c|}{ Animals } & \multirow{2}{*}{$\begin{array}{c}\text { Positive } \\
\text { (n) }\end{array}$} & \multirow{2}{*}{$\begin{array}{c}\text { Positive }^{1} \\
(\%)\end{array}$} & \multirow{2}{*}{$\begin{array}{c}\text { Positive }^{2} \\
(\%)\end{array}$} & \multirow{2}{*}{$\mathrm{P}$} \\
\hline & & $\mathrm{n}$ & $\%$ & & & & \\
\hline \multirow{2}{*}{ Breed } & Mixed & 113 & 45.2 & 23 & 20.4 & 69.7 & \multirow{2}{*}{0.002} \\
\hline & Pure & 137 & 54.8 & 10 & 7.3 & 30.3 & \\
\hline \multirow[b]{2}{*}{ Sex } & Male & 107 & 42.8 & 10 & 9.3 & 30.3 & \multirow{2}{*}{0.134} \\
\hline & Female & 143 & 57.2 & 23 & 16.1 & 69.7 & \\
\hline \multirow{2}{*}{ Age } & $<24$ months & 136 & 54.4 & 12 & 8.8 & 36.4 & \multirow{2}{*}{0.020} \\
\hline & $\geq 24$ months & 114 & 45.6 & 21 & 18.4 & 63.6 & \\
\hline Total & -- & 250 & 100 & 33 & -- & 100 & -- \\
\hline
\end{tabular}

Positive $^{1}=$ Relation among the positive animals within a category and the total of animals of its category.

Positive $^{2}=$ Relation among the positive animals within a category and the total of positive animals.

$\mathrm{P}=$ descriptive level of the $\chi^{2}$ test.

This is the first report of the occurrence of antibodies against $N$. canimum in beef cattle from the region of Guarapuava.

The occurrence of antibodies against $N$. caninum in beef cattle of the region of Guarapuava, PR is $13.2 \%$. Animals of mixed breed presented higher rates of positive serum for $N$. caninum $(\mathrm{P}=0.002)$. Age showed positive association with the occurrence of antibodies against $N$. caninum $(\mathrm{P}=0.02)$, indicating that the horizontal transmission plays an important role in the epidemiology of this coccidia in the evaluated herds.

\section{REFERENCES}

ARMENGOL, R.; PABON, M.; SANTOLARIA, P.; CABEZON, O.; ADELANTADO, C.; YANIZ, J.; LOPEZGATIUS, F.; ALMERIA, S. Low seroprevalence of Neospora caninum infection associated with the Limousin breed in cow-calf herds in Andorra, Europe. Journal of Parasitology, v.93, n.5, p.1029-1032, 2007.

BAAR, B.C.; CONRAD, P.A.; DUBEY, J.P.; ANDERSON, M.L. Neospora-like encephalomyelitis in a calf: pathology, ultrastructure and immunoreactivity. Journal of Veterinary Diagnosis Investigation, v.3, n.1, p.39-46, 1991.

BANALES, P.; FERNANDEZ, L.; REPISO, M.V.; GIL, A.; DARGATZ, D.A.; OSAWA, T. A nationwide survey on seroprevalence of Neospora caninum infection in beef cattle in Urugay. Veterinary Parasitology, v.139, n.1/3, p.15-20, 2006.

BARLING, K.S.; MCNEILL, J.W.; THOMPSON, J.A.; PASCHAL, J.C.; McCOLLUM III, F.T.; CRAIG, T.M.; ADAMS, L.G. Association of serologic status for Neospora caninum with postweaning weight gain and carcass measurements in beef calves. Journal of the American Veterinary Medical Association, v.217, n.9, p.1356-1360, 2000.

BARTELS, C.J.M.; ARNAIZ-SECO, J.I.; RUIZ-SANTAQUITERA, A.; BJÖRKMAN, C.; FRÖSSLING, J.; BL-
UMRÖDER, D.VON; CONRATHS, F.J.; SCHARES, G.; MAANEN, C. VAN; WOUDA, W.; ORTEGA-MORA, L. M. Supranational comparison of Neospora caninum seroprevalences in cattle in Germany, The Netherlands, Spain and Sweden. Veterinary Parasitology, v.137, n.1/2, p.17-27, 2006 .

BJERKÁS, I.; MOHN, S.F.; PRESTHUS, J. Unidentified cyst-forming sporozoan causing encephalomyelitis and myositis in dogs. Zeitschrift fur Parasitenkunde, v.70, p.271-274, 1984.

CONRAD, P.A.; SVERLOW, K.W.; ANDERSON, M.L.; ROWE, J.; BONDURANT, R.; TUTER, G.; BREITMEYER, R.; PALMER, C.; THURMOND, M.; ARDANS, A. Detection of serum antibody responses in cattle with natural or experimental Neospora infections. Journal of Veterinary Diagnosis Investigation, v.5, n.4, p.572-578, 1993.

DAVISON, H.C.; FRENCH, N.P.; TREES, A.J. Herdspecific and age-specific seroprevalence of Neospora caninum in 14 British dairy herds. Veterinary Record, v.144, n.20, p.547-550, 1999.

DUBEY, J.P.; LINDSAY, D.S. A review of Neospora caninum and neosporosis. Veterinary Parasitology, v.67, n.1, p.1-59, 1996.

GARCIA-VAZQUEZ, Z.; ROSARIO-CRUZ, R.; MEJIAESTRADA, F.; RODRIGUEZ-VIVAS, I.; ROMEROSALAS, D.; FERNANDEZ-RUVALCABA, M.; CRUZVAZQUEZ, C. Seroprevalence of Neospora caninum antibodies in beef cattle in three southern states of Mexico. Tropical Animal Health and Production, v.41, n.5, p.749-753, 2009.

GENNARI, S.M. Neospora caninum no Brasil: Situação atual da pesquisa. Revista Brasileira de Parasitologia Veterinária, v.13, p.23-27, 2004. Suplemento 1.

GUIMARÃES JUNIOR, J.S.; SOUZA, S.L.P.; BERGAMASCHI, D.P.; GENNARI, S.M. Prevalence of Neospora caninum antibodies and factors associated with their 
presence in dairy cattle of the north of Paraná state, Brazil. Veterinary Parasitology, v.124, n.1/2, p.1-8, 2004.

IBGE - INSTITUTO BRASILEIRO DE GEOGRAFIA E ESTATÍSTICA. Banco de Dados Agregados: Censo Agropecuário de 2010. Disponível em: <http:/ / www.sidra.ibge.gov.br/bda/tabela/protabl. asp?c $=73 \& z=t \& o=1 \& \mathrm{i}=\mathrm{P}>$. Acesso em 31 out. 2011.

MELO, C.B.; LEITE, R.C.; SOUZA, G.N.; LEITE, R.C. Freqüência de infecção por Neospora caninum em dois diferentes sistemas de produção de leite e fatores predisponentes à infecção em bovinos em Minas Gerais. Revista Brasileira de Parasitologia Veterinária, v.10, n.2, p.67-74, 2001.

MELO, D.P.G.; SILVA, A.C.; ORTEGA-MORA, L.M.; BASTOS, S.A.; BOAVENTURA, C.M. Prevalência de anticorpos anti-Neospora caninum em bovinos das microrregiões de Goiânia e Anápolis, Goiás, Brasil. Revista Brasileira de Parasitologia Veterinária, v.15, n.3, p.105-109, 2006.

MINERVINO, A.H.H.; RAGOZO, A.M.A.; MONTEIRO, R.M.; ORTOLANI, E.L.; GENNARI, S.M. Prevalence of Neospora caninum antibodies in cattle from Santarém, Pará, Brazil. Research in Veterinary Science, v.84, n.2, p.254-256, 2008.

OSAWA, T.; WASTLING, J.; ACOSTA, L.; ORTELLADO, C.; IBARRA, J.; INNES, E.A. Seroprevalence of Neospora caninum infection in dairy and beef cattle in Paraguay. Veterinary Parasitology, v.110, n.1/2, p.17-23, 2002.

PRANDO MOORE, D.; CAMPERO, C.M.; ODEON, A.C.; POSSO, M.A.; CANO, D.; LEUNDA, M.R.; BASSO, W.; VENTURINI, M.C.; SPATH, E. Seroepidemiology of beef and dairy herds and fetal study of Neospora caninum in Argentina. Veterinary Parasitology, v.107, n.4, p.303-316, 2002.
R DEVELOPMENT CORE TEAM. R: A language and environment for statistical computing. Vienna: R Foundation for Statistical Computing, 2008., ISBN 3-900051-07-0. URL: <http:/ /www.R-project.org. 2009>.

RAGOZO, A.M.A.; PAULA, V.S.O.; SOUZA, S.L.P.; BERGASMASCHI, D.P.; GENNARI, S.M. Ocorrência de anticorpos anti-Neospora caninum em soros bovinos procedentes de seis estados brasileiros. Revista Brasileira de Parasitologia Veterinária, v.12, n.1, p.33-37, 2003.

SARTOR, I.F.; GARCIA FILHO, A.; VIANNA, L.C.; PITUCO, E.M.; PAI, V.D.; SARTOR, R. Ocorrência de anticorpos anti-Neospora caninum em bovinos leiteiros e de corte da região de Presidente Prudente, SP. Arquivos do Instituto Biológico, São Paulo, v.72, n.4, p.413-418, 2005.

STOESSEL, Z.; TAYLOR, L.F.; MCGOWAN, M.R.; COLEMAN, G.T.; LANDMANN, J.K. Prevalence of antibodies to Neospora caninum within central Queensland beef cattle. Australian Veterinary Journal, v.81, n.3, p.165-166, 2003.

VOGEL, F.S.F.; ARENHART, S.; BAUERMANN, F.V. Anticorpos anti-Neospora caninum em bovinos, ovinos e bubalinos no Estado do Rio Grande do Sul. Ciência Rural, v.36, n.6, p.1948-1951, 2006.

WALDNER, C. L. Serological status for N. caninum, bovine viral diarrhea virus, and infectious bovine rhinotracheitis virus at pregnancy testing and reproductive performance in beef herds. Animal Reproduction Science, v.90, n.3/4, p.219-242, 2005.

Received on $22 / 11 / 10$

Accepted on 30/4/12 